\title{
Gene expression analysis of overwintering mountain pine beetle larvae suggests multiple systems involved in overwintering stress, cold hardiness, and preparation for spring development.
}

Jeanne A. Robert, Tiffany Bonnett, Caitlin Pitt, Luke J. Spooner, Jordie Fraser, Macaire M.S. Yuen, Christopher I. Keeling, Jörg Bohlmann, Dezene P.W. Huber

Cold-induced mortality has historically been a key aspect of mountain pine beetle, Dendroctonus ponderosae Hopkins (Coleoptera: Curculionidae), population control, but little is known about the molecular basis for cold tolerance in this insect. We used RNA-seq analysis to monitor gene expression patterns of mountain pine beetle larvae at four time points during their overwintering period - early-autumn, late-autumn, early-spring, and late-spring. Changing transcript profiles over the winter indicates a multipronged physiological response from larvae that is broadly characterized by gene transcripts involved in insect immune responses and detoxification during the autumn. In the spring, although transcripts associated with developmental process are present, there was no particular biological process dominating the transcriptome. 
1 Title:

2 Gene expression analysis of overwintering mountain pine beetle larvae suggests multiple

3 systems involved in overwintering stress, cold hardiness, and preparation for spring

4 development.

5 Authors: Jeanne A. Robert ${ }^{1 *}$, Luke J. Spooner ${ }^{1}$, Caitlin Pitt ${ }^{1}$, Tiffany Bonnett ${ }^{1}$, Jordie

6 Fraser $^{1}$, Macaire M. S. Yuen ${ }^{2}$, Christopher I. Keeling ${ }^{3}$, Jörg Bohlmann², and Dezene

7 Huber1

Affiliations:

${ }^{1}$ Department of Ecosystem Science and Management, University of Northern British Columbia, Prince George, British Columbia, Canada.

${ }^{2}$ Michael Smith Laboratories, University of British Columbia, Vancouver, British Columbia, Canada.

${ }^{3}$ Department of Biological Sciences, Simon Fraser University, Burnaby, British Columbia, Canada.

*corresponding author

Jeanne Robert, Ph.D.

Regional Forest Entomologist

Omineca \& Northeast

Ministry of Forests, Lands and Natural Resource Operations

499 George Street - 5th floor

Prince George, BC, V2L 1 R5

Telephone: 250-561-3461

Email: Jeanne.Robert@gov.bc.ca 


\section{Abstract:}

33

34 Cold-induced mortality has historically been a key aspect of mountain pine beetle, Dendroctonus 35 ponderosae Hopkins (Coleoptera: Curculionidae), population control, but little is known about 36 the molecular basis for cold tolerance in this insect. We used RNA-seq analysis to monitor gene 37 expression patterns of mountain pine beetle larvae at four time points during their overwintering 38 period - early-autumn, late-autumn, early-spring, and late-spring. Changing transcript profiles 39 over the winter indicates a multipronged physiological response from larvae that is broadly 40 characterized by gene transcripts involved in insect immune responses and detoxification during 41 the autumn. In the spring, although transcripts associated with developmental process are 42 present, there was no particular biological process dominating the transcriptome. 43

44 
45

46

47

48

49

50

51

52

53

54

55

56

57

58

59

60

61

62

63

64

65

66

67

68

69

70

71

72

73

74

75

\section{Introduction:}

Changing climate and large contiguous stands of susceptible lodgepole pine (Pinus contorta Douglas) have resulted in a large mountain pine beetle, Dendroctonus ponderosae Hopkins (Coleoptera: Curculionidae) outbreak in British Columbia and other parts of western North America (Raffa et al. 2008). The beetle and its fungal associates are projected to kill an estimated 750 million cubic meters of merchantable pine in British Columbia by 2017 (Natural Resources Canada 2015). The large scale of this outbreak in British Columbia, in combination with the expansion of mountain pine beetle into previously unaffected areas of jack pine, Pinus bankisana Lamb, forests in Alberta (Cullingham et al. 2011), have caused substantial economic losses in British Columbia (Schneider et al. 2010) and continue to have massive ecological effects on the landscape.

Cold-induced mortality has historically been a key aspect of mountain pine beetle population control. The mountain pine beetle spends much of its typically one-year life cycle as larvae in the phloem tissue of susceptible host trees. While they overwinter under the bark, larvae have had, under typical conditions, to survive winter temperatures below $-30^{\circ} \mathrm{C}(\mathrm{Cole}$ 1981). Mountain pine beetle larvae possess cold tolerance mechanisms, such as the production of glycerol (Bentz and Mullins 1999) that enable supercooling of insect bodily fluids and tolerance of temperatures far below freezing. However, if a cold snap occurs early in winter, before the larvae have become cold acclimated, massive mortality can occur (Bale 2002). Cold-induced mortality has historically controlled bark beetle populations in British Columbia and prevented the insects from moving further north or east than their historically known range. Because of the recent move of this insect across the Rocky Mountains and into the jack pine forests of Alberta (Cullingham et al. 2011, Janes et al. 2014), understanding the cold tolerance mechanisms of mountain pine beetle is becoming increasingly important for forest management and the development of predictive models.

We used RNA-seq analysis to monitor transcript profiles of mountain pine beetle larvae at four time points during their overwintering period - early-autumn, late-autumn, early-spring, and late-spring. Changing transcript profiles over the winter indicates a multipronged approach to cold readiness, overwintering, and transition into spring development in mountain pine beetle larvae. We uncovered shifts in transcript levels for several groups of genes that are likely to be important in the overwintering success of mountain pine beetle larvae. 
77 Methods and Materials:

78

79

80

81

82

83

84

85

86

87

88

89

90

91

92

93

94

95

96

97

98

99

100

101

102

103

104

105

106

\section{Collection of larval specimens}

Overwintering larvae were collected as described in Bonnett et al. 2012. In brief, larvae were sampled from eleven naturally infested lodgepole pine trees located at two sampling sites near Tête Jaune Cache, British Columbia, Canada (N 53 $3^{\prime} 36.00^{\prime \prime}$, W $119^{\circ} 36^{\prime} 54.00^{\prime \prime}$ and N $52^{\circ}$ $\left.55^{\prime} 4.00^{\prime \prime}, \mathrm{W} 119^{\circ} 21^{\prime} 23.00^{\prime \prime}\right)$. Each tree was fitted with three iButton temperature data loggers (Maxim, Sunnyvale, CA) that recorded ambient temperature every thirty minutes. Overwintering mountain pine beetle larvae were live-collected from under the bark, immediately flash frozen with liquid nitrogen in individual vials in the field, transported on dry ice, and stored at $-80^{\circ} \mathrm{C}$ until RNA extractions were conducted. Collection dates were 26 September 2008, 7 November 2008, 25 March 2009, and 27 May 2009.

\section{RNA extractions}

Immediately prior to RNA extractions, larval beetles were transitioned to $-20^{\circ} \mathrm{C}$ in RNAlater-ICE Frozen Tissue Transition Solution (Ambion, Life Technologies) according to the manufacturer's protocol, and placed in individual wells of a 96 -well, $1 \mathrm{~mL}$ round bottom polypropylene block (Corning Life Sciences) with one stainless steel grinding ball per well. RNA extractions were performed using the MagMAX-96 Total RNA Isolation Kit (Ambion, Life Technologies). Prior to extraction, RNAlater-ICE solution was removed by pipette, and 100 $\mu \mathrm{L}$ of lysis/binding solution from the MagMax-96 Total RNA Isolation Kit was immediately added to each sample well. Samples were ground for eight cycles (1500 strokes/min for 30 seconds followed by 30 seconds on ice) using a Geno/Grinder 2000 (SPEX CertiPrep). Instructions for the MagMax-96 Total RNA Isolation Kit were followed with a few minor modifications: when initially transferring samples from the grinding plate to the processing plate, the $60 \mu \mathrm{L}$ of isopropanol was added directly to the wells in the grinding plate to aid with sample transfer; during the DNA digestion step, $60 \mu \mathrm{L}$ of diluted TURBO DNase was added to each sample to ensure complete DNA degradation; before the final elution step, the elution buffer was heated to $70^{\circ} \mathrm{C}$ to ensure maximum bead dispersion, as suggested in the troubleshooting guide. RNA isolates from individual larvae were assessed for concentration and purity on a Nanodrop1000 Spectrophotometer (Thermo Fisher Scientific). 
108

109

110

111

112

113

114

115

116

117 118

119

120

121

122

123

124

125

126

127

128

129

130

131

132

133

134

135

136

137

\section{RNA sample pooling and replicates}

For the RNA-seq analysis, we used four biological replicates for each of the four sampling dates. Due to the small size of the larvae, each 'biological' replicate was comprised of pooled individual larvae. For the small September larvae, up to eight RNA extractions from individual larvae were pooled to get a single biological replicate. For the November, March, and May larvae, four individuals were pooled for each biological replicate. Pooled RNA samples were concentrated using the RNeasy Mini Kit (Qiagen), following the instructions for the RNA Cleanup Protocol. An aliquot of purified RNA for each biological replicate, containing from 5$11 \mu \mathrm{g}$ of RNA in a maximum volume of $100 \mu \mathrm{L}$, was submitted to the Canada's Michael Smith Genome Sciences Centre (Vancouver, BC, Canada) for whole transcriptome shotgun sequencing.

\section{RNA-seq method}

Paired-end Illumina HiSeq 2000 platform sequencing was performed as described in Robert et al. (2013). 50bp sequence reads were requested, although $75 \mathrm{bp}$ reads were generated for some of the sequencing lanes because of advancing sequencing technologies. The 16 samples were multiplexed into four sequencing lanes, with one replicate of each treatment randomly assigned per lane so that every lane contained all four sampling dates. The paired-end fastq files for each library were mapped to the 13,088 gene models identified in the male mountain pine beetle genome sequence (Keeling et al. 2013) via CLC Genomics Workbench (http://www.clcbio.com/; CLC bio) using the parameters listed in Robert et al. (2013). The average fragment length for paired-end reads was approximately $220 \mathrm{bp}$. Read counts are used as a measure of transcript expression for a given gene model in each sample.

The raw RNA-seq data is available at the National Center for Biotechnology Information Sequence Read Archive (NCBI SRA) database (accession numbers: SRX1043704 to SRX1043719) under the TRIA umbrella BioProject (PRJNA169907) that identifies aggregated research project data generated from the TRIA research collaborations on mountain pine beetle systems genomics.

35 DESeq statistical analysis based on Anders and Huber (2010) was also performed as described in Robert et al. 2013 to calculate fold-changes for each gene as well as p-values adjusted (padj) for multiple comparisons using a Benjamini-Hochberg correction (Benjamini and 
138 Hochberg, 1995). We used a $0.1 \%$ false discovery rate (padj $<0.001$ ) to identify transcript

139 expression levels that were significantly different between timepoints. The DESeq output is

140 publicly available via a DOI-based repository (NB: we can provide the data if needed for review

141 and make it publicly available when the paper is accepted).

142

143 Results:

\section{Sequencing results}

145 Sixteen libraries were sequenced with four biological replicates at each time point (Table

146 1). Overall, 581 transcripts (representing $4.43 \%$ of the 13,088 gene models, or predicted genes,

147 identified in the draft mountain pine beetle genome) with significant shifts in expression

148 occurred uniquely between the time points in September and November (Autumn) and 534

149 (representing $4.08 \%$ of the gene models identified in the draft genome) occurred uniquely

150 between the time points in March to May (Spring); 145 transcripts (representing 1.12\% of the

151 gene models in the draft genome) showed significantly shifts in both the fall and winter (Figure

152 1). Of the shared 145 transcripts, 107 increased in autumn and decreased in the spring whereas

15329 transcripts showed the opposite pattern (i.e. decreased in autumn and increased in spring).

154 The remaining nine significantly changing transcripts either both increased in autumn and spring,

155 or both decreased in autumn and spring.

156 Transcriptome changes during autumn (September to November)

157 Between September and November, 726 transcripts showed significantly different

158 expression levels (Bonferroni adjusted p-value $<0.001$ ). Of these 726,458 were significantly up-

159 regulated (ranging from 1.6-fold increase to $>100$-fold increase) and 268 were significantly

160 down-regulated (ranging from a 1.7-fold decrease to $>300$-fold decrease).

161 The largest fold changes that occurred between sampling dates in September and in

162 November were gene transcripts annotated in the broad group of stress response physiology. The

163 top expression fold-change was annotated as a putative galactose-specific C-type lectin (102.75-

164 fold increase), an enzyme associated with the immune response in insects (e.g. Yu et al. 2005).

165 Of the 11 transcripts that were significantly up-regulated over 10-fold between September and

166 November (Table 2): four were of unknown function and were associated with physiological

167 stress arising from insect contact with pathogens and host plant defenses as well as general

168 cellular stabilization responses in response to stress. These six transcripts were annotated as a 
169 putative alpha-esterase, glycoside hydrolase family protein 48, cyclin-dependent kinase 5

170 activator, two heat shock proteins, and a glutathione S-transferase.

171 Conversely, of the 41 transcripts that showed the largest ( $>10$-fold) down-regulation

172 between September and November, almost half (19) have no known function, a further nine were

173 annotated as insect cuticle proteins, and the remaining 13 transcripts were variously annotated,

174 but contain a number of catabolic enzymes such as proteases and lyases (Table 3).

175

176 Transcript changes during spring (March to May)

177 Between the sampling points in March and May, 679 gene transcripts showed significant 178 differences (Bonferroni adjusted p-value $<0.001$ ). The 456 transcripts significantly up-regulated

179 between March and May, as a group, had very different annotations than the transcript changes 180 associated with the autumn period between September and November. The top six transcripts, in 181 terms of fold-changes, between March and May all exhibited well over a 100 fold increase. Of

182 these six transcripts, the greatest up-regulation was $>1000$-fold increase in a transcript annotated

183 as a cathepsin L-like proteinase, a digestive enzyme in beetles (Murdock et al. 1987). The second

184 highest fold change (202-fold up-regulation) is annotated as a pol (polyp-specific) gene similar

185 to a sequence expressed in the polyp stage of the freshwater cnidarian, Hydra magnipapillata.

186 The remaining transcripts that exhibited $>100$-fold up-regulation were all without functional

187 annotations in current databases.

188

189 Patterns in transcript changes during overwintering (September to May)

190 Of the transcripts that exhibited increased levels between September and November, 107

191 also decreased significantly between March and May. Many of these were annotated as genes

192 responsible for cold tolerance and as indicators of physiological response to stress. Transcripts

193 associated with cold tolerance included those for two enzymes - glycerol-3-phosphate

194 dehydrogenase and glycerol kinase - that immediately precede the production of glycerol. Those

195 two were also significantly up-regulated in the autumn, stable over the winter, and significantly

196 down-regulated in the spring (Figure 2).

197 Other transcripts annotated as proteins that play a role in cold tolerance included those for 198 a trehalose receptor that increased 14-fold, and for several heat shock proteins. For example, two 199 heat shock protein transcripts and a heat shock transcription factor transcript that increased 
200 between September and November, significantly decreased during the spring (Figure 3). A

201 significant change in glutathione-S-transferase (Figure 4) and cytochromes P450 (Table 4) also

202 occur for larvae in the autumn and spring.

203

\section{Discussion:}

205

As mountain pine beetle larvae grow and develop within the infested host tree, they are

206 exposed during the autumn and winter to decreasing temperatures, conifer host chemical defenses (Bohlmann 2012, Trapp and Croteau 2001, Keeling and Bohlmann 2006a, 2006b), and pathogens (Winder et al. 2010). In addition, overwintering mountain pine beetle larvae may be exposed to other possible changes in their environment such as nutrient and moisture content of host tissue or changing microbiomes of the host tissue and the feeding galleries. Many of the major fold changes in the larvae transcriptome observed between September and November

212 occur in a group of transcripts that can be broadly grouped as "stress response genes". Because

213 this is a period in which mountain pine beetle larvae have shown the highest mortality (Bale

214 2002), the general working hypothesis is that larvae die if they are not fully acclimated,

215 including the production anti-freeze compounds. Our results support this, but additionally

216 suggest that early winter larvae are under enormous physiological stress from other factors as

217 well, such as, for example, host chemical defenses and pathogens. The autumn transcriptome

218 signature is consistent with proteomic evidence of an increase in oxidative stress in

219 overwintering larvae between September and November (Bonnet et al. 2012). Within this

220 response however, it is difficult to separate the response to a seasonal drop in temperature from

221 the other environmental pressures occurring at this time. The diversity of enzyme groups and

222 pathways that are up-regulated between September and November indicates a multi-pronged

223 approach to cold hardiness and overwintering. We identified several groups of genes likely to be

224 associated with one or more "stress" factors: cold hardiness (heat shock proteins, glycerol

225 biosynthesis, sugars and animo acids), immune-responsive proteins, and detoxification

226 mechanisms.

227 Between September and November, two heat shock protein (Hsp) transcripts are strongly

228 up-regulated (annotated as similar to Hsp68 in Tribolium cataneum), an additional two

229 transcripts are significantly up-regulated to a lesser extent (one 90kDa protein and one small heat

230 shock protein 21), and a heat shock protein transcription factor transcript is significantly up- 
231 regulated as well. Heat shock proteins are associated with abiotic stresses such as temperature 232 change, drought, dehydration, and chemical exposure (King and MacRae 2015, Zhao and Jones 233 2012) - all of which occur during the early months of larval growth and development under the 234 bark of the host tree. These transcripts likely play a role in protein stabilization or sequestration 235 in preparation for below-freezing temperatures during the winter months. Similar expression of 236 heat shock proteins has been shown in Drosophila melanogaster, specifically expression of 237 Hsp68 was induced by acute cold stress. (Colinet and Hoffmann 2012; Colinet et al. 2010) and in 238 leafminer species (Huang and Kang 2007; Huang et al. 2009). The expression pattern of a 239 putative HSP transcription factor, an Hsp 68a, and a small Hsp 21 (a large increase in the early 240 winter, stable transcription throughout the winter months, then a large decrease during the onset 241 of spring) (Figure 3), identifies these gene candidates for further study.

242 Glycerol is a known cryoprotectant in mountain pine beetle and is one of the few 243 metabolites that have been shown to accumulate in overwintering larvae (Benz and Mullins 244 1999). Our results support the importance of glycerol production in early winter and support 245 similar quantitative RT-PCR results found in overwintering larvae in Fraser (2011) and Fraser et 246 al. (unpublished); studies that were conducted using overwintering larvae collected concurrently 247 with the larvae sampled for this study. Key enzymes in the two catalytic steps preceding the final 248 synthesis of glycerol were significantly up-regulated between September and November (Figure 249 2). This suggests that production of glycerol is increased between September and November, in 250 agreement with previous work (Fraser 2011). Also in agreement with Fraser (2011), our results 251 further suggest that glycerol is biosynthesized via dihydroxyacetone phosphate (DHAP) and 252 glycerol-3-phosphate (G3P) rather than via glyceraldehyde (Figure 2). Although the 253 glyceraldehyde route could conceivably also be responsible for increased glycerol synthesis in 254 some circumstances, we did not find evidence for this pathway in our data set, which supports 255 the findings in Fraser (2011) as well. Although a protein identified as trehalose-phosphate synthase was up-regulated in the 257 autumn and down-regulated in the spring in the proteomic data reported by Bonnett et al. (2012), 258 only a single gene transcript in our data set was annotated as a trehalose 6-phosphate synthase 259 isoform. The expression of this transcript did not change significantly in the autumn, through the 260 winter, or in the spring. Rozsypal et al. (2013) also found that levels of trehalose and proline 261 remain at high, constant levels for overwintering codling moth larvae and suggest that these 
262 metabolites are important for protein and membrane stabilization during bouts of freezing 263 temperatures as described in Jain and Roy (2009). Our data suggests a similar pattern for 264 mountain pine beetle overwintering larvae.

265 In addition to preparation for sub-freezing temperatures, mountain pine beetle larvae also 266 showed a stress response in the form of the expression of immune response transcripts. The 267 largest significant transcript increase between September and November was annotated as a 268 galactose-specific C-type lectin. In Drosophila, these enzymes are associated with immune 269 response, but the precise role of specific proteins in this large group remains unclear (Tanji et al. 270 2006). We identified 11 gene models in the mountain pine beetle genome annotated as 'lectins'; 271 two of these were highly up-regulated in larvae between September and November. This could

272 represent either a local response to a particular pathogen, or a general stress-induced response as 273 a result of toxic conditions of a colonized host tree.

274 In autumn, several genes associated with detoxification of host metabolites are also 275 strongly up-regulated. Glutathione S-transferases and an alpha-esterases are two enzyme groups 276 that have been implicated with detoxification of xenobiotics, such as host defense compounds, in 277 insects (Pitt et al. 2014; Robert et al. 2012; Campbell et al. 2003; Kostaropoulos et al. 2001). As 278 insect larvae are still living and growing in a dying tree, they would be exposed to not only 279 decreasing temperatures, but also to the full suite of conifer host chemical defenses (Clark et al., 280 2012, Bohlmann 2012, Keeling and Bohlmann 2006a, 2006b). A large group of enzymes 281 commonly associated with detoxification of plant defense compounds, cytochromes P450 282 (Feyereisen 1999), are also significantly up-regulated in our data set during autumn. Eleven gene 283 transcripts annotated as cytochromes P450 increase significantly in the autumn. Of these 11, 284 three also significantly decrease in the spring (CYP345E3, CYP349B1, and CYP9Z36). These 285 enzymes would be strong candidates for a role in larval detoxification of host tissue. CYP345E3 286 is similar in sequence to CYP345E2, which modifies monoterpene substrates (Keeling et al. 287 2013). Expressed sequence tag data suggests CYP345E3 is not localized to the antenna like 288 CYP345E2, but found in the midgut and fat body tissues of adults (Keeling et al. 2016), also 289 suggesting a role in detoxification. Interestingly, several of the cytochromes P450 that increased 290 significantly in larvae during autumn (CYP6CR2, CYP4EX1, CYP9AP1, and CYP6BW2) 291 comprise almost the entire list of significantly decreasing cytochrome P450s in starved versus 292 fed adult mountain pine beetle (Robert et al. 2012). Because these transcripts do not decrease in 
293 spring, are elevated in antennae-rich mountain pine beetle expressed sequence tag libraries

294 (Keeling et al. 2012), and implicated in odourant degradation processes in adult cotton

295 leafworms (Pottier et al. 2012), it may be possible that the development of odour processing

296 begins as early as the formation of eye-antennal imaginal discs in early instar larvae (Haynie and

297 Bryant 2005). In addition, CYP6CR2 has high sequence similarity to CYP6CR1, which is an

298 epoxidase in exo-brevicomin biosynthesis, a pheromone produced by male mountain pine beetle

299 after leaving the brood tree, but that decreases during host tree selection and mating (Song et al.

300 2014). Theses cytochromes P450 could also play a role as the developing larvae navigate and

301 feed on host tissue containing a diversity of associated fungi that can act as a food source, or

302 threat, under the bark (Lee et al. 2006). The opposite process occurs in the adults, as after host

303 colonization, odorant detection and processing becomes irrelevant as the focus shifts to mating

304 and reproduction (Robert et al. 2012).

305 In spring, larvae must begin the physiological process of preparing for emergence,

306 dispersal flight, and a chance of reproduction during the subsequent summer months as well as a

307 number of unidentified processes that require further study. For larvae that survived the winter,

308 the late-instar preparation for pupation shows decreased levels of stress response gene transcripts

309 and increases in developmental gene transcripts generally. The various transcripts showing

310 greater than 100-fold increases March and May are largely without known functional annotation

311 in current databases. Developmental processes of overwintering beetles in the spring thus seem

312 to represent a largely unknown set of processes that need further investigation. The function of

313 the pol in Hydra spp. polyps is unknown, but possible functions include control of osmotic

314 pressure, secretion of this protein to form an outer protective layer for the polyp, secretion as a

315 component of the extracellular matrix, secretion as an anti-bacterial defense, or secretion as a

316 signaling molecule (Aerne et al. 1996). The distant phylogenetic relationship of cnidarians to

317 beetles make it difficult to predict potential function. Because this transcript is strongly and

318 significantly up-regulated (greater than 200-fold increase in expression) between March and

319 May, the protein product could play a significant role in bark beetle late-stage developmental

320 processes.

321

322 Conclusions: 
324 environment during autumn. This response can be broadly characterized by gene transcripts

325 involved in insect immune responses and detoxification, which are strongly up-regulated in the

326 autumn and occurs within a background of preparation for winter via the production of glycerol,

327 heat shock proteins, trehalose and other known strategies to tolerant below-freezing

328 temperatures. In the spring, although gene transcripts associated with developmental process are

329 present, the bulk of the transcripts are not yet associated with known gene functions.

\section{References:}

332 Aerne B, Gröger H, Schuchert P, Spring J, and Volker S. 1996. The polyp and its medusa: a 333 molecular approach. Scientia Marina. 60(1):7-16.

Bale JS. 2002. Insects and low temperatures: from molecular biology to distributions and abundance. Philosophical Transactions of the Royal Society B: Biological Sciences.

338 357(1423):849-862.

Benjamini Y, Hochberg Y.1995. Controlling the False Discovery Rate: a Practical and Powerful Approach to Multiple Testing. Journal of the Royal Statistical Society. Series B

341 (Methodological). 57(1):289-300.

343 Bonnett TR, Robert JA, Pitt C, Fraser J, Keeling CI, Bohlmann J, Huber DPW. 2012. Global and 344 comparative proteomic profiling of overwintering and developing mountain pine beetle, 345 Dendroctonus ponderosae (Coleoptera: Curculionidae), larvae. Insect Biochemistry and 346 Molecular Biology. 42(12): 890-901. doi:10.1016/j.ibmb.2012.08.003

Bohlmann J. 2012. Pine terpenoid defences in the mountain pine beetle epidemic and in other conifer pest interactions: specialized enemies are eating holes into a diverse, dynamic and durable defence system. Tree Physiology. 32(8):943-945. doi: 10.1093/treephys/tps065 
352 Campbell PM, Robin GCDeQ, Court LN, Dorrian SJ, Russell RJ, and Oakeshott JG. 2003.

353 Developmental expression and gene/enzyme identifications in the alpha esterase gene cluster of

354 Drosophila melanogaster. 12(5):459-471. DOI: 10.1046/j.1365-2583.2003.00430.x

355

356 Clark, E.L., Huber, D.P.W., and Carroll, A.L. 2012. The legacy of attack: implications of high

357 phloem resin monoterpene levels in lodgepole pines following mass attack by mountain pine

358 beetle, Dendroctonus ponderosae Hopkins. Environmental Entomology 41: 392-398.

359

360 Cole W. 1981. Some risks and causes of mortality in mountain pine beetle populations: A long361 term analysis. Researches on Population Ecology 23:116-144.

362

363 Colinet H, Hoffmann AA. 2012. Comparing phenotypic effects and molecular correlates of

364 developmental, gradual and rapid cold acclimation responses in Drosophila melanogaster.

365 Funct. Ecol. 26:84-93.

366

367 Colinet H, Lee SF, Hoffmann A. 2010. Temporal expression of heat shock genes during cold

368 stress and recovery from chill coma in adult Drosophila melanogaster. FEBS J. 277:174-85

369

370 Feyereisen R. Insect P450 Enzymes. Annual Review of Entomology. 44:507-533. DOI:

371 10.1146/annurev.ento.44.1.507

372

373 Fraser J. 2011. Cold tolerance and seasonal gene expression in Dendroctonus ponderosae. M.Sc.

374 thesis. University of Northern British Columbia (Canada), ProQuest, UMI Dissertations

375 Publishing. MR75167.

376

377

378 Haynie JL and Bryant PJ. 2005. Development of the eye-antenna imaginal disc and

379 morphofenesis of the adult head in Drosophila melanogaster. Journal of Experimental Zoology.

380 237(3):293-308. DOI: 10.1002/jez.1402370302

381

382 
383 Jain NK and Roy I. 2009. Effect of trehalose on protein structure. Protein Science. 18(1): 24-36.

384 doi: $10.1002 /$ pro.3

385

386

Janes JK., Yisu L, Keeling CI, Yuen MMS, Boone CK, Cooke JEK, Bohlmann J, Huber DPW,

387 Murray BW, Coltman DW, and Sperling FAH. 2014. How the mountain pine beetle

388 (Dendroctonus ponderosae) breached the Canadian Rocky Mountains. Molecular biology and 389 evolution. 31(7):1803-1815.

390

391 Keeling C.I., Bohlmann J. 2006a. Genes, enzymes and chemicals of terpenoid diversity in the 392 constitutive and induced defence of conifers against insects and pathogens. New Phytol.

393 170:657-675. DOI: 10.1111/j.1469-8137.2006.01716.x

394

395 Keeling C.I., Bohlmann J. 2006b. Diterpene resin acids in conifers. Phytochemistry 67:2415-

396 2423. DOI: 10.1016/j.phytochem.2006.08.019

397

398

Keeling CI, Henderson H, Li M, Yuen M, Clark EL, Fraser JD, Huber DPW, Liao NY, Docking 399 TR, Birol I, Chan SK, Taylor GA, Palmquist D, Jones SJM, Bohlmann J (2012) Transcriptome 400 and full-length cDNA resources for the mountain pine beetle, Dendroctonus ponderosae 401 Hopkins, a major insect pest of pine forests. Insect Biochem. Mol. Biol. 42(8): 525-36. doi: 402 10.1016/j.ibmb.2012.03.010.

403

404 Keeling CI, Li M, Sandhu HK, Henderson H, Yuen MMS, and Bohlmann J. 2016. Quantitative 405 metabolome, proteome, and transcriptome analysis of midgut and fat body tissues in the 406 mountain pine beetle, Dendroctonus ponderosa Hopkins, and insights into pheromone 407 biosynthesis. Insect Biochemistry and Molecular Biology. 70:170-183.

408 doi:10.1016/j.ibmb.2016.01.002

409

410 Keeling CI, Yuen MMS, Liao NY, Docking TR, Chan SK, Taylor GA, Palmquist DL, Jackman 411 SD, Nguyen A, Li M, Henderson H, Janes JK, Zhao Y, Pandoh P, Moore R, Sperling FA, Huber 412 DP, Birol I, Jones SJ, Bohlmann J.. (2013) Draft genome of the mountain pine beetle, 
413 Dendroctonus ponderosae Hopkins, a major forest pest. Genome Biol. 14(3): R27.

414 doi: $\underline{10.1042 / \mathrm{BJ} 20051921}$

415

416 King A and MacRae TH. Insect heat shock proteins during stress and diapause. Annual Review 417 of Entomology. 60:59-75. DOI: 10.1146/annurev-ento-011613-162107

418

419 Kostaropoulos I, Papadopoulos AI, Metaxakis A, Boukouvala E, Papadopoulou-Mourkidou E.

420 Glutathione S-transferase in the defence against pyrethroids in insects. Insect Biochemistry and

421 Molecular Biology. 31(4-5):313-319. doi:10.1016/S0965-1748(00)00123-5

422

423 Huang L-H, Kang L. 2007. Cloning and interspecific altered expression of heat shock protein

424 genes in two leafminer species in response to thermal stress. Insect Mol. Biol. 16:491-500 425

426 Huang L-H, Wang C-Z, Kang L. 2009. Cloning and expression of five heat shock protein genes

427 in relation to cold hardening and development in the leafminer, Liriomyza sativa. J. Insect

428 Physiol. 55:279-85

429

430 Lee S, Kim J-J, and Breuil C. 2006. Diversity of fungi associated with mountain pine beetle, 431 Dendroctonus ponderosae, and infested lodgepole pines in British Columbia. Mountain Pine 432 Beetle Initiative Working Paper. Canadian Forest Service. Crown publication: Victoria British 433 Columbia.

434

435 Pitt C, Robert JA, Bonnett TR, Keeling CI, Bohlmann J, Huber DPW. 2014. Proteomics 436 indicators of rapidly shifting physiology from whole Moutain Pine Beetle, Dendroctonus 437 ponderoase (Coleoptera: Curculionidae), adults during early host colonization. PLoS ONE 9(10): 438 e110673. doi:10.1371/journal.pone.0110673

439

440 Pottier M-A, Bozzolan F, Chertemps T, Jacquin-Joly E, Lalouette L, Siaussat D, and Maïbèche441 Coisne M. 2012. Cytochrome P450s and cytochrome P450 reductase in the olfactory organ of the 442 cotton leafworm Spodoptera littoralis. Insect Molecular Biology. 21(6):568-580.

443 doi:10.1111/j.1365-2583.2012.01160.x 
444

445 Robert JA, Pitt C, Bonnett TR, Yuen MM, Keeling CI, Bohlmann J, Huber DPW. Disentangling

446 detoxification: Gene expression analysis of feeding Mountain Pine Beetle illuminates molecular-

447 level host chemical defense detoxification mechanisms. PLoS One. 8(11): e77777.

448 doi:10.1371/journal.pone.0077777

449

450 Rozsypal J, Kostal V, Sahradnickova H, and Simek P. 2013. Overwintering strategy and

451 mechanisms of cold tolerantce in the Codling Moth (Cydia pomonella). PLoS One. 8(4): e61745.

452 doi: 10.1371/journal.pone.0061745

453

454 Song M, Gorzalski A, Nguyen TT, Liu X, Jeffrey C, Blomquist GJ, and Tittiger C. 2014. Exo-

455 Brevicomin biosynthesis in the fat body of the mountain pine beetle, Dendroctonus ponderosae.

456 Journal of Chemical Ecology. 40:181-189. doi: 10.1007/s10886-014-0381-9

457

458 Tanji T, Ohashi-Kobayashi A, and Natori S. 2006. Participation of a galactose-specific C-type

459 lectin in Drosophila immunity. Biochemistry Journal. 396(pt 1):127-138.

460

461 Winder RS, Macey DE, Cortese J. 2010. Dominant bacteria associated with broods of mountain

462 pine beetle, Dendroctonus ponderosae (Coleoptera: Curculionidae, Scolytinae). Journal of the

463 Entomological Society of British Columbia. 107:43-56.

464

465 Yu X-Q, Tracy ME, Ling E, Scholz FR, and Trenczek T. 2005. A novel c-type immulection-3

466 from Manduca sexta is translocated from hemolymph into the cytoplasm of hemocytes. Insect

467 Biochemistry and Molecular Biology. 35(4):285-295. doi:10.1016/j.ibmb.2005.01.004

468

469 Zhao L and Jones WA. Expression of heat shock protein genes in insect stress response.

470 Invertebrate Survival Journal. 9:93-101. 


\section{Table $\mathbf{1}$ (on next page)}

Sequence data summary

Table 1 - Summary information for sequence data mapped to the male mountain pine beetle genome (Keeling et al. 2013). 


\begin{tabular}{|l|l|l|l|l|l|}
\hline Sampling date & Replicate & $\begin{array}{l}\text { NCBI } \\
\text { accession } \\
\text { number }\end{array}$ & $\begin{array}{l}\text { Read } \\
\text { length }\end{array}$ & $\begin{array}{l}\text { Total pairs } \\
\text { mapped }\end{array}$ & $\begin{array}{l}\text { Uniquely } \\
\text { mapped } \\
\text { pairs }\end{array}$ \\
\hline Sept. 26, 2008 & 1 & SRX1043704 & 50 & $51,228,868$ & $20,383,049$ \\
\hline & 2 & SRX1043705 & 50 & $75,540,024$ & $29,715,613$ \\
\hline & 3 & SRX1043706 & 75 & $66,662,746$ & $26,832,203$ \\
\hline & 4 & SRX1043707 & 75 & $41,552,862$ & $16,802,040$ \\
\hline Nov. 7, 2008 & 1 & SRX1043708 & 50 & $64,102,946$ & $25,410,259$ \\
\hline & 2 & SRX1043709 & 50 & $52,214,600$ & $20,525,750$ \\
\hline & 3 & SRX1043710 & 75 & $36,280,228$ & $14,402,268$ \\
\hline & 4 & SRX1043711 & 75 & $71,571,952$ & $28,268,130$ \\
\hline Mar. 25, 2009 & 1 & SRX1043712 & 50 & $59,279,874$ & $23,425,001$ \\
\hline & 2 & SRX1043713 & 50 & $54,870,752$ & $21,496,616$ \\
\hline & 3 & SRX1043714 & 75 & $58,248,050$ & $23,687,547$ \\
\hline & 4 & SRX1043715 & 75 & $67,215,526$ & $26,666,241$ \\
\hline May 27, 2009 & 1 & SRX1043716 & 50 & $55,731,196$ & $21,959,708$ \\
\hline & 2 & SRX1043717 & 50 & $43,999,520$ & $17,182,971$ \\
\hline & 3 & SRX1043718 & 75 & $73,662,736$ & $29,422,596$ \\
\hline & 4 & SRX1043719 & 75 & $51,860,004$ & $20,696,257$ \\
\hline & & & & & \\
\hline
\end{tabular}




\section{Table 2 (on next page)}

Positive fold changes greater than 10

Differentially expressed transcripts (identified by the gene model ID in the mountain pine beetle draft genome (Keeling et al. 2013)) with positive fold changes $>10$ between September and November, and their annotations. 


\begin{tabular}{|c|c|c|c|}
\hline $\begin{array}{c}\mathrm{NCBI} \\
\text { accession }\end{array}$ & $\begin{array}{l}\text { Fold } \\
\text { change }\end{array}$ & $\begin{array}{l}\text { Adjusted } \\
\text { p-value }\end{array}$ & Annotation \\
\hline YQE_05764 & 102.7 & $1.19 \times 10^{-6}$ & $\begin{array}{l}\text { galactose-specific C-type lectin } \\
\text { [Aedes aegypti] }\end{array}$ \\
\hline YQE_02030 & 85.9 & $1.18 \times 10^{-48}$ & $\begin{array}{l}\text { hypothetical protein } \\
\text { [Tribolium castaneum] }\end{array}$ \\
\hline YQE_04779 & 19.1 & $6.43 \times 10^{-13}$ & $\begin{array}{l}\text { alpha-esterase } \\
\text { [Tribolium castaneum] }\end{array}$ \\
\hline YQE_03841 & 15.8 & $4.46 \times 10^{-12}$ & $\begin{array}{l}\text { hypothetical protein } \\
\text { [Tribolium castaneum] }\end{array}$ \\
\hline YQE_05176 & 14.2 & 0.00052 & $\begin{array}{l}\text { glycoside hydrolase family protein } 48 \\
\text { [Dendroctonus ponderosae] }\end{array}$ \\
\hline YQE_2031 & 14.1 & $3.2 \times 10^{-08}$ & $\begin{array}{l}\text { GF10288 } \\
\text { [Drosophila ananassae] }\end{array}$ \\
\hline YQE_5800 & 12.7 & $1.03 \times 10^{-5}$ & $\begin{array}{l}\text { cyclin-dependent kinase } 5 \text { activator } \\
\text { [Tribolium castaneum] }\end{array}$ \\
\hline YQE_ 10688 & 11.9 & $2.25 \times 10^{-8}$ & No hits \\
\hline YQE_06804 & 11.9 & $1.19 \times 10^{-21}$ & $\begin{array}{l}\text { heat shock protein } 68 \\
\text { [Tribolium castaneum] }\end{array}$ \\
\hline YQE_06803 & 11.1 & $5.65 \times 10^{-50}$ & $\begin{array}{l}\text { heat shock protein } 68 \\
\text { [Tribolium castaneum] }\end{array}$ \\
\hline YQE_11126 & 10.8 & $2.69 \times 10^{-7}$ & $\begin{array}{l}\text { putative glutathione s-transferase } \\
\text { [Tribolium castaneum] }\end{array}$ \\
\hline
\end{tabular}

1 


\section{Table 3(on next page)}

Negative fold changes greater than 10

Differentially expressed transcripts (identified by the gene model ID in the mountain pine beetle draft genome (Keeling et al. 2013)) with negative fold changes >10 between September and November, and their annotations. 


\begin{tabular}{|c|c|c|c|}
\hline $\begin{array}{c}\text { NCBI } \\
\text { accession }\end{array}$ & $\begin{array}{c}\text { Fold } \\
\text { change }\end{array}$ & $\begin{array}{l}\text { Adjusted } \\
p \text {-value }\end{array}$ & Annotation \\
\hline YQE 09553 & -10.18 & 0.00022 & Pupal cuticle protein \\
\hline YQE_09888 & -10.20 & $8.08 \times 10^{-05}$ & $\begin{array}{l}\text { CLIP-domain serine protease } \\
\text { [Tribolium castaneum] }\end{array}$ \\
\hline YQE_07481 & -11.16 & $6.50 \times 10^{-8}$ & $\begin{array}{l}\text { hypothetical protein } \\
\text { [Tribolium castaneum] }\end{array}$ \\
\hline YQE 10790 & -11.30 & $7.35 \times 10^{-20}$ & No hits \\
\hline YQE_10908 & -11.71 & 0.00048 & $\begin{array}{l}\text { cytochrome P450 } \\
\text { [Tribolium castaneum] }\end{array}$ \\
\hline YQE_04818 & -12.02 & $4.45 \times 10^{-5}$ & $\begin{array}{l}\text { cuticle protein } \\
\text { [Tribolium castaneum] }\end{array}$ \\
\hline YQE 09921 & -12.41 & 0.00073 & No hits \\
\hline YQE 09126 & -12.48 & $5.14 \times 10^{-9}$ & No hits \\
\hline YQE_02052 & -12.71 & $4.51 \times 10^{-5}$ & $\begin{array}{l}\text { hypothetical protein } \\
\text { [Tribolium castaneum] }\end{array}$ \\
\hline YQE_07386 & -13.09 & $4.45 \times 10^{-5}$ & $\begin{array}{l}\text { cuticle protein } \\
\text { [Tribolium castaneum] }\end{array}$ \\
\hline YQE 09538 & -13.52 & $3.47 \times 10^{-15}$ & No hits \\
\hline YQE_05819 & -13.67 & $7.13 \times 10^{-5}$ & $\begin{array}{l}\text { PREDICTED: similar to pol } \\
\text { [Hydra magnipapillata] }\end{array}$ \\
\hline YQE_03141 & -13.73 & $3.88 \times 10^{-15}$ & $\begin{array}{l}\text { hypothetical protein } \\
\text { [Tribolium castaneum] }\end{array}$ \\
\hline YQE_06846 & -13.95 & $1.61 \times 10^{-18}$ & $\begin{array}{l}\text { polysaccharide lyase } \\
\text { [Dendroctonus ponderosae] }\end{array}$ \\
\hline YQE_02456 & -14.26 & $1.83 \times 10^{-12}$ & $\begin{array}{l}\text { nicotinic acetylcholine receptor } \\
\text { [Tribolium castaneum] }\end{array}$ \\
\hline YQE_02053 & -14.29 & $3.34 \times 10^{-8}$ & $\begin{array}{l}\text { hypothetical protein } \\
\text { [Tribolium castaneum] }\end{array}$ \\
\hline YQE_01398 & -14.98 & $8.58 \times 10^{-5}$ & $\begin{array}{l}\text { acid phosphatase } \\
\text { [Tribolium castaneum] }\end{array}$ \\
\hline YQE_02457 & -15.16 & $9.54 \times 10^{-7}$ & $\begin{array}{l}\text { nicotinic acetylcholine receptor } \\
\text { [Musca domestica] }\end{array}$ \\
\hline YQE 08291 & -16.07 & $2.20 \times 10^{-16}$ & No hits \\
\hline YQE 08290 & -16.85 & $1.07 \times 10^{-12}$ & No hits \\
\hline YQE_11867 & -17.96 & $1.57 \times 10^{-5}$ & $\begin{array}{l}\text { hypothetical protein } \\
\text { [Tribolium castaneum] }\end{array}$ \\
\hline YQE_04236 & -18.73 & 0.00022 & $\begin{array}{l}\text { glucose dehydrogenase } \\
\text { [Tribolium castaneum] }\end{array}$ \\
\hline YQE_08964 & -20.00 & $1.78 \times 10^{-73}$ & $\begin{array}{l}\text { endopolygalacturonase [ } \\
\text { Dendroctonus ponderosae] }\end{array}$ \\
\hline YQE_06880 & -22.23 & 0.00064 & $\begin{array}{l}\text { ectodermal protein } \\
\text { [Tribolium castaneum] }\end{array}$ \\
\hline YQE_10193 & -23.82 & $1.02 \times 10^{-9}$ & $\begin{array}{l}\text { hypothetical protein } \\
\text { [Tribolium castaneum] }\end{array}$ \\
\hline YQE 08292 & -26.06 & $4.58 \times 10^{-6}$ & No hits \\
\hline YQE_08203 & -26.81 & 0.00057 & $\begin{array}{l}\text { cuticle protein } \\
\text { [Culex quinquefasciatus] }\end{array}$ \\
\hline YQE_09008 & -31.69 & $1.25 \times 10^{-6}$ & $\begin{array}{l}\text { larval cuticle protein } \\
\text { [Apriona germari] }\end{array}$ \\
\hline YQE_10491 & -32.00 & 0.00012 & $\begin{array}{l}\text { Hypothetical protein } \\
\text { [Tribolium castaneum] }\end{array}$ \\
\hline YQE_04635 & -33.75 & 0.00026 & $\begin{array}{l}\text { hypothetical protein } \\
\text { [Tribolium castaneum] }\end{array}$ \\
\hline
\end{tabular}




\begin{tabular}{|c|c|c|l|}
\hline YQE_06881 & -34.89 & $2.75 \times 10^{-11}$ & No hits \\
\hline YQE_02898 & -36.77 & 0.00037 & $\begin{array}{l}\text { Hypothetical protein } \\
\text { [Tribolium castaneum }]\end{array}$ \\
\hline YQE_03979 & -55.12 & 0.00056 & $\begin{array}{l}\text { Hypothetical protein } \\
\text { [Drosophila pseudoobscura pseudoobscura] }\end{array}$ \\
\hline YQE_02037 & -70.29 & 0.00014 & $\begin{array}{l}\text { cuticular protein } \\
{[\text { Tribolium castaneum }]}\end{array}$ \\
\hline YQE_05018 & -124.19 & $9.00 \times 10^{-5}$ & $\begin{array}{l}\text { hypothetical protein } \\
\text { [Tribolium castaneum }]\end{array}$ \\
\hline YQE_01043 & -157.19 & $1.89 \times 10^{-5}$ & $\begin{array}{l}\text { cuticular protein } \\
\text { [Tribolium castaneum }]\end{array}$ \\
\hline YQE_03142 & -181.29 & 0.00093 & $\begin{array}{l}\text { hypothetical protein } \\
\text { [Tribolium castaneum }]\end{array}$ \\
\hline YQE_02038 & -206.30 & $8.84 \times 10^{-5}$ & $\begin{array}{l}\text { cuticular protein } \\
\text { [Tribolium castaneum] }\end{array}$ \\
\hline YQE_06565 & -298.81 & $1.06 \times 10^{-7}$ & $\begin{array}{l}\text { Hypothetical protein } \\
\text { [Drosophila erecta] }\end{array}$ \\
\hline YQE_00517 & -301.59 & 0.00044 & No hits \\
\hline YQE_07189 & -313.04 & $9.44 \times 10^{-7}$ & $\begin{array}{l}\text { cuticle protein } \\
\text { [Tribolium castaneum }]\end{array}$ \\
\hline
\end{tabular}

1 


\section{Table 4(on next page)}

P450 table

Table 4 - Fold changes and adjusted p-values for cytochromes P450 that increased in the autumn sampling period (transcript expression levels between September and November) and then either decreased or did not change through the winter (November and March) and spring (March and May) sampling periods. An asterisk indicates a significant difference (Bonferroni adjusted $p$-value $<0.001$ ) between time points within the sampling period. Shaded rows indicate transcripts that increased significantly in the autumn and decreased significantly the in the spring. 


\begin{tabular}{|c|c|c|c|c|c|c|c|}
\hline & & & Autumn & 4 & Winter & & Spring \\
\hline $\begin{array}{c}\text { NCBI } \\
\text { accession }\end{array}$ & CYP ID & $\begin{array}{c}\text { Fold } \\
\text { change }\end{array}$ & $\begin{array}{c}\text { Adjusted } \\
\mathrm{p} \text {-value }\end{array}$ & $\begin{array}{c}\text { Fold } \\
\text { change }\end{array}$ & $\begin{array}{l}\text { Adjusted } \\
\text { p-value }\end{array}$ & $\begin{array}{c}\text { Fold } \\
\text { change }\end{array}$ & $\begin{array}{c}\text { Adjusted } \\
\mathrm{p} \text {-value }\end{array}$ \\
\hline YQE_10907 & CYP6CR2 & $8.01^{*}$ & $<0.0001$ & -2.79 & 0.0055 & 1.25 & 0.2165 \\
\hline YQE_12528 & CYP345E3 & $4.86^{*}$ & $<0.0001$ & -1.85 & 0.1206 & $-4.15^{\star}$ & $<0.0001$ \\
\hline YQE_07362 & CYP4G56 & $3.89^{*}$ & $<0.0001$ & 1.00 & 1.0000 & -0.60 & 0.3440 \\
\hline YQE_01611 & CYP4EX1 & $3.29^{*}$ & 0.0001 & -1.76 & 0.1901 & 0.04 & 0.9668 \\
\hline YQE_00788 & CYP6BW2 & $3.16^{*}$ & $<0.0$ & $-3.98^{*}$ & $<0.0001$ & 1.27 & 0.0678 \\
\hline YQE_06842 & CYP9AP1 & $3.03^{*}$ & $<0.0001$ & -2.37 & 0.0016 & -0.48 & 0.4740 \\
\hline YQE_05824 & CYP4CV1 & $2.43^{*}$ & 0.0003 & -1.13 & 0.9780 & -0.72 & 0.5954 \\
\hline YQE_02159 & CYP349B1 & $2.37^{*}$ & $<0.0001$ & -1.48 & 0.1789 & $-5.34^{*}$ & $<0.0001$ \\
\hline YQE_11788 & CYP6DF1 & $2.22^{*}$ & $<0.0001$ & -1.42 & 0.2963 & -0.42 & 0.5217 \\
\hline YQE_07361 & CYP9Z36 & $2.11^{*}$ & 0.0010 & $-3.66^{*}$ & $<0.0001$ & $-2.00^{*}$ & 0.0004 \\
\hline YQE_12976 & CYP6BS2 & $1.99^{*}$ & 0.0004 & -1.81 & 0.0170 & 1.00 & 0.0543 \\
\hline
\end{tabular}

1 


\section{1}

Venn diagram of total transcriptome

Figure 1 - Venn diagram showing the number of significantly changing transcripts unique to autumn (brown circle), and unique to spring (blue circle), and those that showed significantly shifts in both autumn and spring (middle). Of the 145 gene transcripts that showed a significant difference in both autumn and spring, 107 increased in autumn and decreased in spring, and 29 are decreased in autumn and then increased in spring. 


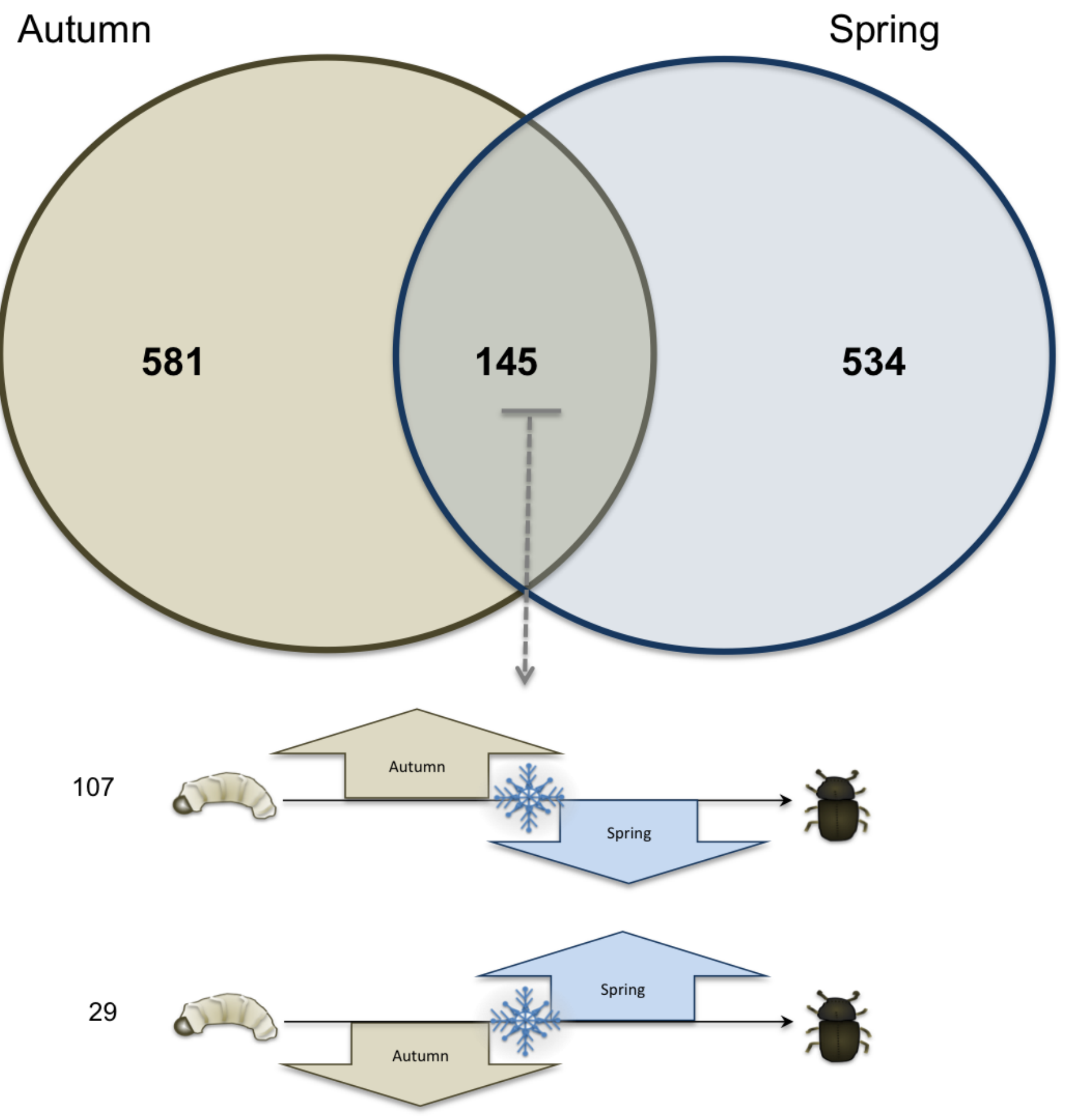




\section{2}

Glycerol biosynthesis

Fi gure 2 - Fold changes between each sampling date through the winter for transcripts annotated as key enzymes in the biosynthetic pathway for glycerol: glycerol-3-phosphate dehydrogenase (G3PDH, YQE_09604) and glycerol kinase (GK, YQE_6814). An asterisk indicates a significant fold change within the two time points measured within each sampling period (Bonferroni adjusted p-value $<0.001$ ). The diagram on the right illustrates a subset of the glycerol biosynthetic pathway (modified with permission from Fraser 2011) showing the location G3PDH and GK as the enzymes that catalyze the steps immediately preceding the production of glycerol. Metabolites are shown in ovals: dihydroxyacetone phosphate (DHAP), glycerol-3-phosphate (G3P), glyceraldehyde (GA); enzymes are shown in rectangles: glycerol3-phosphate dehydrogenase (G3PDH), glycerol kinase (GK), alcohol dehydrogenase (ADH).
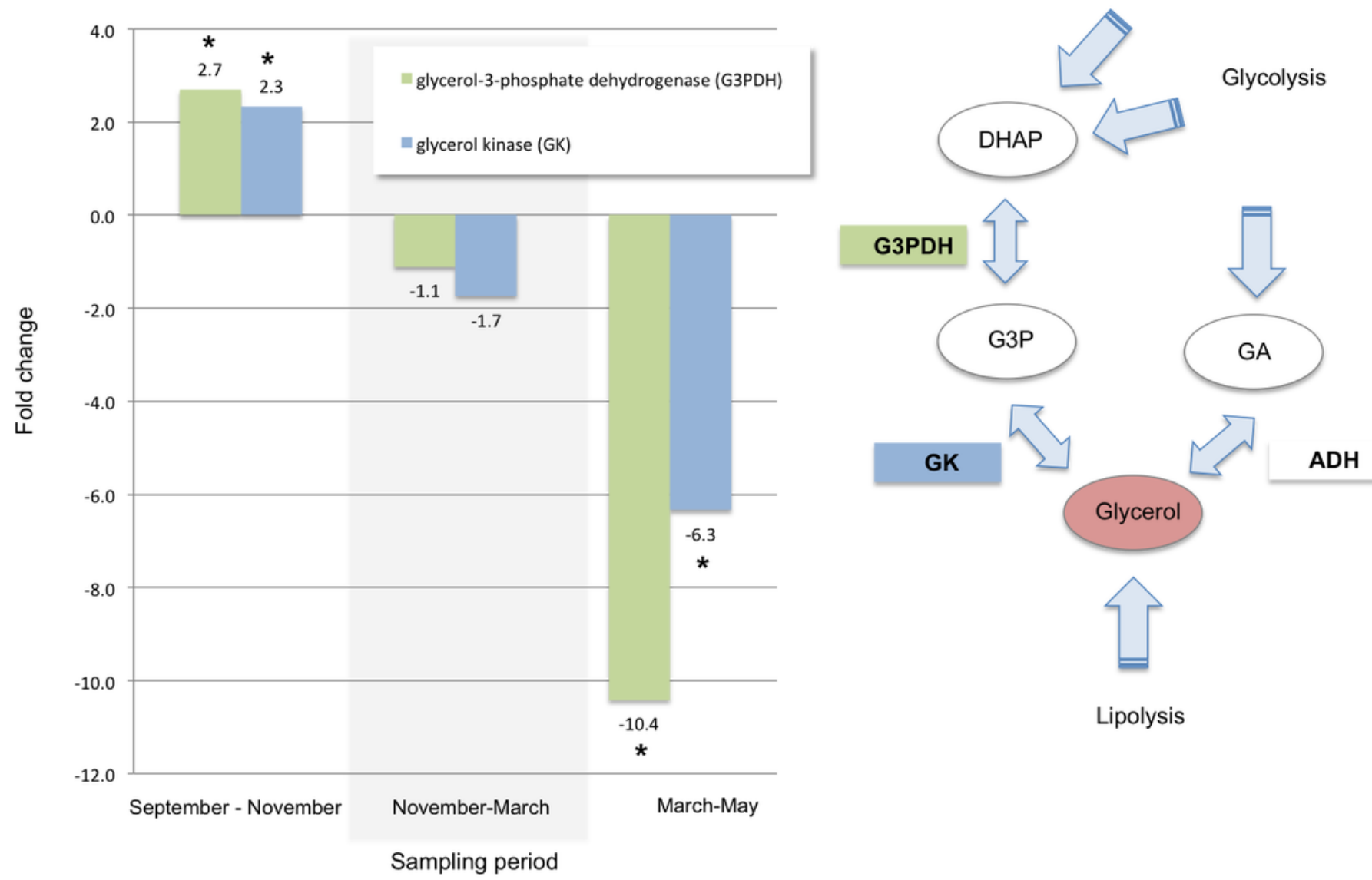

Lipolysis 
3

Heat shock proteins

Figure 3 - Fold changes between each sampling date through the winter for transcripts annotated with: a heat shock transcription factor (YQE_06804), heat shock protein 68a (YQE_05849), and small heat shock protein 21 (YQE_02436). An asterisk indicates a significant fold change between the time points within each sampling period (Bonferroni adjusted $p$-value $<0.001$ ).

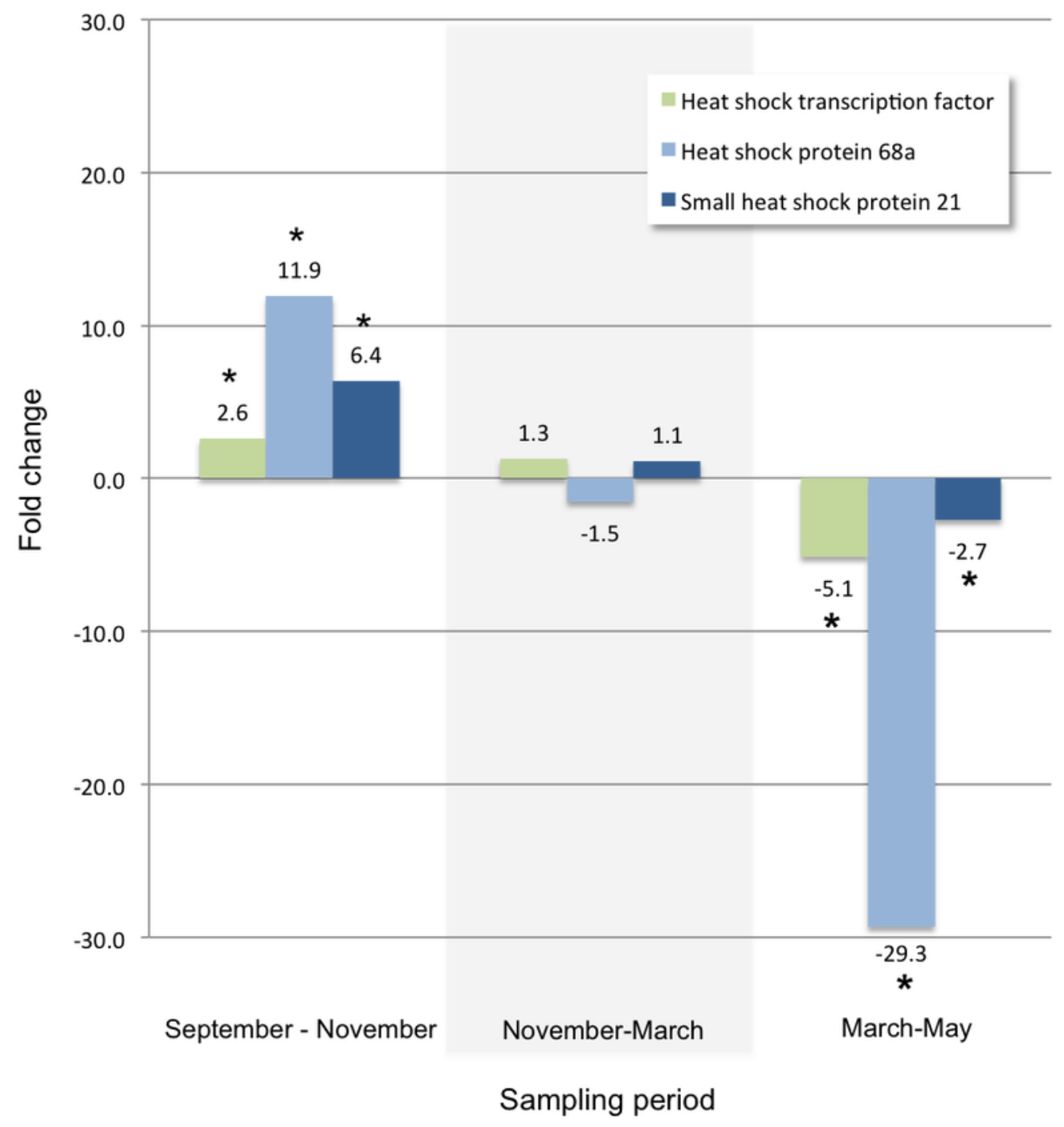


4

Glutathione-S-transferase

Figure 4 - Fold changes between each sampling date through the winter for transcripts annotated as glutathione-S-transferase 1 (YQE_11126) and glutathione-S-transferase 2 (YQE_02640). An asterisk indicates a significant fold change between the time points within each sampling period (Bonferroni adjusted p-value $<0.001$ ).

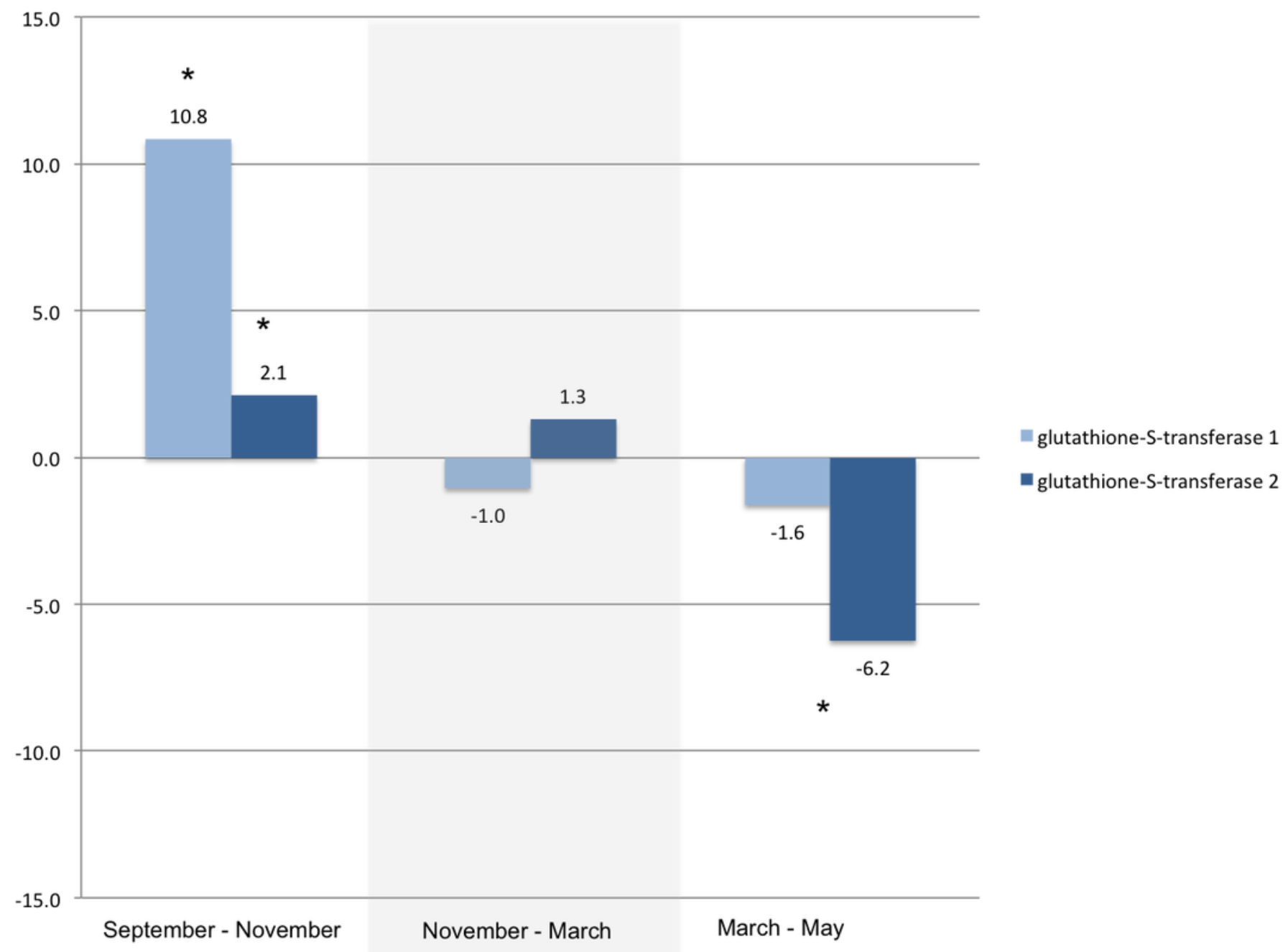

Sampling period 